\title{
The Effect of Natural Water with Cow Dung and Agricultural Waste Ratio on Biogas Production from Anaerobic Co-Digestion
}

\author{
${ }^{1}$ NaponKeanoi, ${ }^{1}$ KanokornHussaro and ${ }^{2}$ Sombat Teekasap \\ ${ }^{1}$ Rattanakosin College for Sustainable Energy and Enviroment, \\ Rajamangala University of Technology Rattanakosin, PuthamonthonSai 5, \\ Salaya, Puthamonthon, NakhonPathom, 73170, Thailand \\ ${ }^{2}$ Department of Mechanical Engineering, Faculty of Engineering, \\ Eastern Asia University, Thanyaburi, PathumThani, 12110, Thailand
}

Received 2013-10-17, Revised 2013-12-07; Accepted 2014-01-22

\begin{abstract}
Global warming caused by energy generation from fossil fuel has accelerated the deployment of renewable fuels such as biogas. In this study, batch fermentation $(5 \mathrm{~L})$ was studied to observe the effect of natural water, cow dung, rice straw and water hyacinth ratio on the biogas and methane production at ambient temperature $\left(31^{\circ} \mathrm{C}\right), 7.1-7.4 \mathrm{of} \mathrm{pH}$ for 52 days. The five types of co-digestion were 2:1:1:1 (digester A), 1:1:1:1 (digester B), 0.5:1:1:1 (digester C), 1:1:1:0 (digester D) and 1:1:0:1 (digester E), respectively. The result showed that the biogas production increased progressively with amount of natural water to raw material. The maximum biogas production and methane concentration was 1650 $\mathrm{mL} /$ days and $61.47 \%$ was obtained at substrate mixture 2:1:1:1 (digester A), which there are suitable of $\mathrm{C}: \mathrm{N}$ ratio at 31.1:1. Natural water, cow dung, rice straw and water hyacinth was mixed for biogas production, have been found to improve highest biogas production compared to those of without rice straw and water hyacinth. Therefore, the mixing natural water, cow dung, rice straw and water hyacinth can improve both biogas production and content of methane in biogas.
\end{abstract}

Keywords: Natural Water, Cow Dung, Agricultural Waste, Rice Straw, Water Hyacinth, Biogas Production, Methane Production and Anaerobic Co-Digestion

\section{INTRODUCTION}

World Energy consumption has continuously increased, while fossil fuel supplies are depleting and oil prices are rising. In addition, emissions from combustion of fossil force policy planners to change energy structure, energy carriers move towards cleaner fuels (Mohammadi et al., 2013; Feiqing and Lu, 2013). Biogas is an excellent alternative energy candidate for the future, especially on global environment impacts, such as greenhouse effect and resource recovery, microbial. Biogas production from renewable biomass reduces fossil fuel dependence, decreases carbon dioxide emission and recovers bio-energy.

The environment-friendly biogas produced from anaerobic digestion can help for utilizing of wastes, such as animal dung, agricultural refuses, municipal solid waste, sewage and etc. (Feiqing and Lu, 2013). Biogas can be used for generating electricity and heat and can also be used as a transportation fuel.

Biogas generation process comprise of four major phases; hydrolysis, acid genesis, acetogenesis and nethanogenesis (Momoh and Nwaogazie, 2011). The hydrolysis phase (stage 1) involves solubilize of complex Corresponding Author: NaponKeanoi, Rattanakosin College for Sustainable Energy and Enviroment, Rajamangala University of Technology Rattanakosin, PuthamonthonSai 5, Salaya, Puthamonthon, NakhonPathom, 73170, Thailand 
plant and animal origin waste materials, which consist mainly of carbohydrates, lipids and proteins, in releasing extracellular enzyme by bacteria. This stage is also known as polymer breakdown stage. For example, the cellulose consisting of polymerized glucose is broken down to dimeric and then to monomeric sugar molecules by cellulolytic bacteria. Acideogenesis and acetogenesis produced in stage 1 is fermented under anaerobic condition into various acids with the help of enzymes produced by the acid forming bacteria. At this stage, the acid-forming bacteria break down molecules of six atoms of carbon (glucose) into less atoms of carbon (acids) molecules. The principal acids produced in this process are acetic acid, propionic acid, butyric acid and ethanol and finally, converse acetic acid into methane and carbon dioxide in the methanogenic phase (Momoh and Nwaogazie, 2011), which can be expressed by the following Equation (1 to 3):

$$
\mathrm{CH}_{3} \mathrm{COOH}-->\mathrm{CH}_{4}+\mathrm{CO}_{2}
$$

Acetic acid Methane Carbon dioxide

$2 \mathrm{CH}_{3} \mathrm{CH}_{2} \mathrm{OH}+\mathrm{CO}_{2}-->\mathrm{CH}_{4}+2 \mathrm{CH}_{3} \mathrm{COOH}$

EthanolCarbon Methane Acetic acid Dioxide

$\mathrm{CO}_{2}+4 \mathrm{H}_{2}-->\mathrm{CH}_{4}+2 \mathrm{H}_{2} \mathrm{O}$

Carbon Hydrogen Methane Water Dioxide

The above equations showed that many products, byproducts and intermediate products are produced in the process of digestion in an anaerobic condition before the final product (methane) is produced.

Biogas yield is affected by temperature, $\mathrm{pH}$, carbon to nitrogen ratio $(\mathrm{C}: \mathrm{N}$ ratio) and loading rate. $\mathrm{A} C: \mathrm{N}$ ratio ranging from 20 to 30 is considered optimum for anaerobic digestion.

Thailand is abundant in agricultural waste resources; Approximately 27 million tons of rice straw, 4 million tons of water hyacinth and 12 million tons of cow dung per year in 2010. These wastes are bunt at random, discarded, or directly discharged into the environment, which result in pollution production (Ling et al., 2012). The water hyacinth, a fast growing plant, caused to a major problems of the whole area. Attempt to control the weed have to spend at high cost and man power, which leading to nothing but temporary removal of the water hyacinths.

This research focuses on the effect of the ratio of natural water, cow dung, rice straw and water hyacinths on quantity of biogas production by anaerobic digestion at ambient temperature. This study aims to achieving the following: (i) chemical content of raw materials are carried out by CHNS analysis, (ii) biogas production by co-digestion on small batch reactors using agricultural wastes and an undefined bacterial consortium derived from anaerobic cow dung compost as inoculum and (iii) analysis of methane content and biogas production are performed by the gas chromatography.

\section{MATERIALS AND METHODS}

\subsection{Materials}

The raw materials used for this experiment were natural water, cow dung, rice straw and water hyacinth, which were collected from LopburiProvice, Thailand. Water hyacinth was dried in the sun for 1 week and grinded to pass through $5 \mathrm{~mm}$ sieve pieces. The collected rice straw was a grinded to about $5 \mathrm{~mm}$ sieve pieces. Then the raw materials were kept in a tightly closed plastic container and stored at ambient temperature of $25-30^{\circ} \mathrm{C}$. The cow dung was sun dried for a period of 2 weeks to preserve its microbial population and then crushed mechanically using a mortar and pestle. Natural water was collected from canal in AmporBanmie, LopburiProvice, Thailand. Raw materials were taken for compositional analysis before the anaerobic digestion tests.

\subsection{Experimental Method}

Production of biogas offer significant advantages flexible use as vehicles fuel or as natural gassubstitute. The experiments were conducted in special designed glass fermenter apparatus that contained one 5L capacity digester vessel and one water displacement gas collection reservoir. Schematic experimental biogas fermentation set upis presented in Fig. 1. The first experiment was performed with anaerobic co-digestion by varying amount of natural water to raw materials ratio (cow dung: rice straw: water hyacinth) were $0.5: 1,1: 1$ and 2:1 and the second experiment was varying the raw material ratio (cow dung: rice straw: water hyacinth) which were $1: 1: 1,1: 1: 0$ and $1: 0: 1$, respectively by fixed amount of natural water at 1 part with ambient temperature for 52 days. Sets of five batch reactors were used as digesters. Each digester contained fixed amount of cow dung as inoculum, but increasing amount of natural water. These digesters were labeled A, B, C, D and $\mathrm{E}$, respectively. Experimental design is presented in Table 1. Composition of batch reactor digester B-D is $1: 1$ of natural water to raw materials ratio, batch reactor digester $\mathrm{A}$ is $0.5: 1$ of natural water to raw materials ratio and batch reactor digester $E$ is $2: 1$ of natural water to raw materials ratio, respectively. 
NaponKeanoi et al. / American Journal of Environmental Science 9 (6): 529-536, 2013

Table 1. List of experimental design for biogas productionat ambient temperature for 52 days

\begin{tabular}{|c|c|c|c|c|c|}
\hline \multirow[b]{2}{*}{ Digester } & \multirow[b]{2}{*}{ Samples } & \multicolumn{4}{|c|}{ Amount of raw material $(\mathrm{kg})$} \\
\hline & & $\begin{array}{l}\text { Natural } \\
\text { water }\end{array}$ & $\begin{array}{l}\text { Cow } \\
\text { dung }\end{array}$ & $\begin{array}{l}\text { Rice } \\
\text { straw }\end{array}$ & $\begin{array}{l}\text { Water } \\
\text { hyacinth }\end{array}$ \\
\hline A & WCRH2111 & 3.52 & 0.59 & 0.590 .59 & \\
\hline B & WCRH1111 & 1.76 & 0.59 & 0.590 .59 & \\
\hline $\mathrm{C}$ & WCRH0.5111 & 0.57 & 0.59 & 0.590 .59 & \\
\hline $\mathrm{D}$ & WCRH1110 & 1.76 & 0.88 & 0.88 & 0 \\
\hline $\mathrm{E}$ & WCRH1101 & 1.76 & 0.88 & 0 & 0.88 \\
\hline
\end{tabular}

Note: WCRH is natural water: Cowdung: Rice straw: Water hyacinth

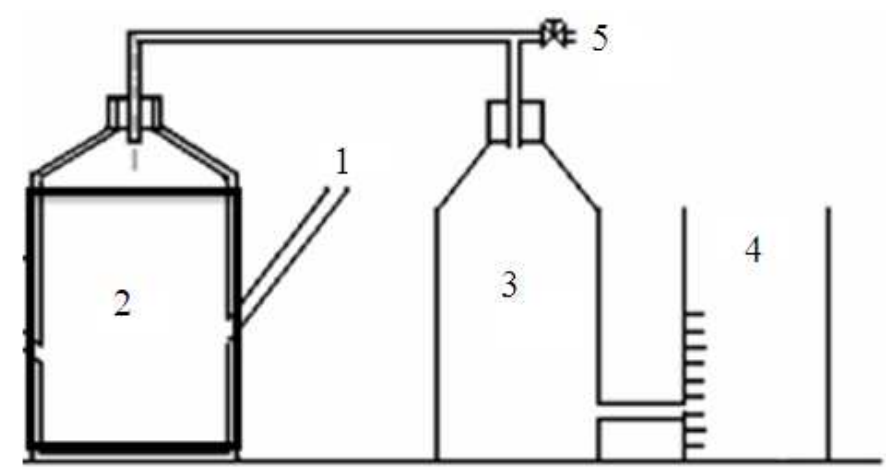

Fig. 1. Schematic of biogas production experimental set-up. (1) raw materialinlet, (2) 5L anaerobic digester, (3) water displacement bottle, (4) measuring scale and (5) on-off valve

\subsection{Characterization}

The compositional analyses of raw material were carried out by $\mathrm{CHNO}$ proximate analysis. Carbon to nitrogen ratio $(\mathrm{C} / \mathrm{N})$ of raw materials analyzed using CHNS/O ANALYZER (Pe2400 SeriesП) at Scientific and Technological Research Equipment, Chulalongkorn University. Analytical methods were gaseous products freed by pyrolysis in high-purity oxygen and were chromatographically separated by frontal analysis by quantitatively thermal conductivity detector. Proximate analysis was done as per Indian Standard 1350 (Gupta et al., 2012), which all analyses were done in triplicate samples: moisture content was determined by drying $10 \mathrm{~g}$ sample in a pre-weight dish at 110 in an electric oven for 1 hour, cooled the dish in desiccator and weighed, repeated the process till weight constant. Volatile matter was determined by heating $1 \mathrm{~g}$ sample in pre-weight silica VM crucible covered with lid at $900^{\circ} \mathrm{C}$ for a period of $7 \mathrm{~min}$ in the muffle furnaces. One-gram sample was heated in preweighed silica crucible without covering with lid in presence of air at $815^{\circ} \mathrm{C}$ for $1 \mathrm{~h}$ and repeated the process till weight constant to Determine Ash. Finally, fixed carbon was determined by calculation [100(moisture + volatile matter + ash $)]$.

The Biochemical Oxygen Demand (BOD) and Chemical Oxygen Demand (COD) of natural water sample was analyzed using the Standard Methods at Chulalongkorn University. Total Solid (TS), Volatile Solids (VS) and $\mathrm{pH}$ were measured according to the standard methods for water examination. TS test and VS test have been done by constant weight drying method. $\mathrm{pH}$ test was determined by using $\mathrm{pH}$ meter. Biogas composition was determined by using a gas chromatography equipped with a Thermal Conductivity Detector (TCD). Helium was used as a carrier gas with a flow rate of $40 \mathrm{~mL} \mathrm{~min}{ }^{-1}$. The temperature of detector was $120^{\circ} \mathrm{C}$. The injection from gasbag was $1 \mathrm{~mL}$.

\section{RESULTS}

\subsection{Characteristics of Raw Material}

Component characteristics of raw materials fed to reactor are summarized in Table 2 . The cow dung used in the experiments contained relatively high solid content. Therefore dilution is required to fit anaerobic 
reactors condition of 8 and 12\% (Nasir et al., 2012). Meanwhile, initial concentration of $\mathrm{COD}$ and $\mathrm{NH}_{3}$-Nof cow dung were at higher value.

Carbons to nitrogen ratio of the substrates feeding to reactor are presented in Table 3. These result showed that digester $\mathrm{A}-\mathrm{C}$ had $\mathrm{C} / \mathrm{N}$ ratio about 31.2, produced total quantity of biogas higher that of digester $\mathrm{D}$ and $\mathrm{E}$ which similar to the previously report by Mohd et al. (2008).

\subsection{Effect of Raw Material Ratio on Biogas Production}

Amount of biogas producefrom digesters A-E against time for are presented in Fig. 2 and Table 4. It was observed that the $\mathrm{pH}$ after experiment commenced lie within the optimum rage for biogas production that is 7.1-7.4. The average temperature during the period of study was $31^{\circ} \mathrm{C}$. The highest amount of biogas of digester $\mathrm{A}>\mathrm{B}>\mathrm{C}>\mathrm{D}>$ Ewere 1650, 1520, 1325, 1200 and $850 \mathrm{~mL} /$ day, respectively. Digester $\mathrm{E}$ with no rice straw and the natural water to raw materials were 1:1 had produced lowest amount of biogas. The low biogas production obtained here could be attributed to the degradation characteristic of biomass composition. Rice straw and water hyacinth are known to contain cellulose and hemicelluloses, which are not easily susceptible to biodegradation. However, the addition of natural water and cow dung to these agricultural wastes led to improvement in biogas production.

The effects of natural water to raw materials $(2: 1,1: 1$ and $0.5: 1)$ on quantity of biogas product were compared between digester A-C. The amount of biogas increased progressively with natural water to raw material ratio.

Digester A (natural water to raw materials ratio, 2:1) produced the highest yield. It does mean therefore that the addition of natural water can improve biogas production by modifying composition of raw materials mixtures. The maximum biogas product is the biogas product obtainable if biomass is allowed to undergo biodegradation for very long period of time in batch reactors (Fig. 2).

\subsection{Methane Concentration of Biogas}

An initial co-digestion study of natural water, cow dung, rice straw and water hyacinth at the ratio of $2: 1: 1: 1$ (digester A), 1:1:1:1 (digester B), 0.5:1:1:1 (digester C), 1:1:1:0 (digester D) and 1:1:0:1 (digester E) were conducted in $5 \mathrm{~L}$ batch reactor, to see the best composition ratio on the amount of biogas and methane production. The effect of feeding composition on methane concentration is shown in Fig. 3.

Table 2. Characteristics of raw materials for biogas production

\begin{tabular}{|c|c|c|c|c|}
\hline $\begin{array}{l}\text { Parameters } \\
\text { water dung }\end{array}$ & $\begin{array}{l}\text { Natural } \\
\text { straw }\end{array}$ & $\begin{array}{l}\text { Cow } \\
\text { hyacinth }\end{array}$ & Rice & Water \\
\hline \multicolumn{5}{|l|}{$\begin{array}{l}\text { - Proximate } \\
\text { analysis }\end{array}$} \\
\hline TS (\%) & - & 72.60 & 92.90 & 59.40 \\
\hline VS (\%) & - & 55.80 & 79.80 & 57.50 \\
\hline Fixed carbon (\%) & - & 18.80 & 15.70 & 14.50 \\
\hline Ash (\%) & - & 19.60 & 9.90 & 23.80 \\
\hline Moisture content (\%) & & 9.60 & 6.30 & 8.30 \\
\hline \multicolumn{5}{|l|}{ - CHNO analysis } \\
\hline $\mathrm{C}$ & - & 20.42 & 35.76 & 27.77 \\
\hline $\mathrm{H}$ & - & 3.85 & 5.66 & 4.09 \\
\hline $\mathrm{N}$ & - & 1.84 & 0.48 & 1.85 \\
\hline $\mathrm{C} / \mathrm{N}$ ratio & - & 11.11 & 82.55 & 14.99 \\
\hline - COD (mg/L) & 28.00 & 136.60 & - & - \\
\hline - BOD (mg/L) & 4.11 & 9.50 & - & - \\
\hline - $\mathrm{NH}_{3}-\mathrm{N}(\mathrm{mg} / \mathrm{L})$ & - & $23,875.00$ & & \\
\hline - $\mathrm{pH} 7.11$ & 7.25 & 6.30 & 6.40 & \\
\hline
\end{tabular}

Table 3. The carbon to nitrogen ratio of substances fed to reactor before fermentation

\begin{tabular}{lll}
\hline Digester & Samples & C/N ratio \\
\hline A & WCRH2111 & 31.20 \\
B & WCRH1111 & 31.20 \\
C & WCRH0.5111 & 31.20 \\
D & WCRH1110 & 46.30 \\
E & WCRH1101 & 13.05 \\
\hline
\end{tabular}


NaponKeanoi et al. / American Journal of Environmental Science 9 (6): 529-536, 2013

Table 4. Biogas product of A-E digester

\begin{tabular}{|c|c|c|c|c|c|}
\hline \multirow[b]{2}{*}{ Time (day) } & \multicolumn{5}{|c|}{ Biogas product (mL/day) } \\
\hline & A digester & $\mathrm{B}$ digester & $\mathrm{C}$ digester & $\mathrm{D}$ digester & E digester \\
\hline 1 & 0 & 0 & 0 & 0 & 0 \\
\hline 2 & 0 & 0 & 0 & 0 & 0 \\
\hline 3 & 0 & 0 & 0 & 0 & 0 \\
\hline 4 & 580 & 565 & 0 & 0 & 0 \\
\hline 5 & 595 & 500 & 370 & 476 & 0 \\
\hline 6 & 620 & 600 & 550 & 496 & 507 \\
\hline 7 & 700 & 650 & 615 & 488 & 507 \\
\hline 8 & 850 & 800 & 700 & 484 & 507 \\
\hline 9 & 1100 & 900 & 800 & 672 & 507 \\
\hline 10 & 1200 & 1100 & 950 & 704 & 507 \\
\hline 11 & 1250 & 1150 & 1000 & 804 & 578 \\
\hline 12 & 1300 & 1200 & 1010 & 1044 & 700 \\
\hline 13 & 1350 & 1250 & 1100 & 1046 & 700 \\
\hline 14 & 1400 & 1300 & 1150 & 1040 & 700 \\
\hline 15 & 1500 & 1400 & 1200 & 1043 & 700 \\
\hline 16 & 1520 & 1450 & 1220 & 1042 & 750 \\
\hline 17 & 1550 & 1480 & 1240 & 1060 & 770 \\
\hline 18 & 1560 & 1480 & 1260 & 1100 & 740 \\
\hline 19 & 1580 & 1490 & 1290 & 1120 & 745 \\
\hline 20 & 1600 & 1500 & 1300 & 1150 & 800 \\
\hline 21 & 1650 & 1520 & 1325 & 1200 & 850 \\
\hline 22 & 1580 & 1480 & 1300 & 1100 & 800 \\
\hline 23 & 1550 & 1450 & 1290 & 1080 & 750 \\
\hline 24 & 1520 & 1400 & 1150 & 1020 & 700 \\
\hline 25 & 1480 & 1300 & 1080 & 1000 & 700 \\
\hline 26 & 1480 & 1250 & 1050 & 980 & 680 \\
\hline 27 & 1400 & 1200 & 1000 & 940 & 650 \\
\hline 28 & 1350 & 1150 & 980 & 920 & 595 \\
\hline 29 & 1320 & 1100 & 950 & 850 & 580 \\
\hline 30 & 1250 & 1080 & 800 & 750 & 580 \\
\hline 31 & 1200 & 1050 & 780 & 710 & 550 \\
\hline 32 & 1180 & 1000 & 760 & 700 & 485 \\
\hline 33 & 1150 & 980 & 750 & 690 & 480 \\
\hline 34 & 1100 & 950 & 730 & 650 & 470 \\
\hline 35 & 1050 & 930 & 720 & 640 & 460 \\
\hline 36 & 1030 & 920 & 720 & 620 & 460 \\
\hline 37 & 1000 & 880 & 710 & 600 & 450 \\
\hline 38 & 980 & 850 & 710 & 600 & 400 \\
\hline 39 & 950 & 820 & 700 & 580 & 400 \\
\hline 40 & 920 & 780 & 700 & 570 & 385 \\
\hline 41 & 900 & 750 & 700 & 550 & 350 \\
\hline 42 & 880 & 730 & 690 & 550 & 330 \\
\hline 43 & 850 & 730 & 690 & 540 & 330 \\
\hline 44 & 850 & 720 & 690 & 540 & 310 \\
\hline 45 & 840 & 720 & 690 & 530 & 300 \\
\hline 46 & 840 & 710 & 680 & 520 & 275 \\
\hline 47 & 835 & 710 & 680 & 520 & 275 \\
\hline 48 & 820 & 700 & 680 & 520 & 275 \\
\hline 49 & 820 & 700 & 670 & 520 & 275 \\
\hline 50 & 820 & 700 & 670 & 520 & 275 \\
\hline 51 & 825 & 700 & 670 & 520 & 275 \\
\hline 52 & 825 & 700 & 670 & 520 & 275 \\
\hline
\end{tabular}


Table 5. Biogas quality parameter.

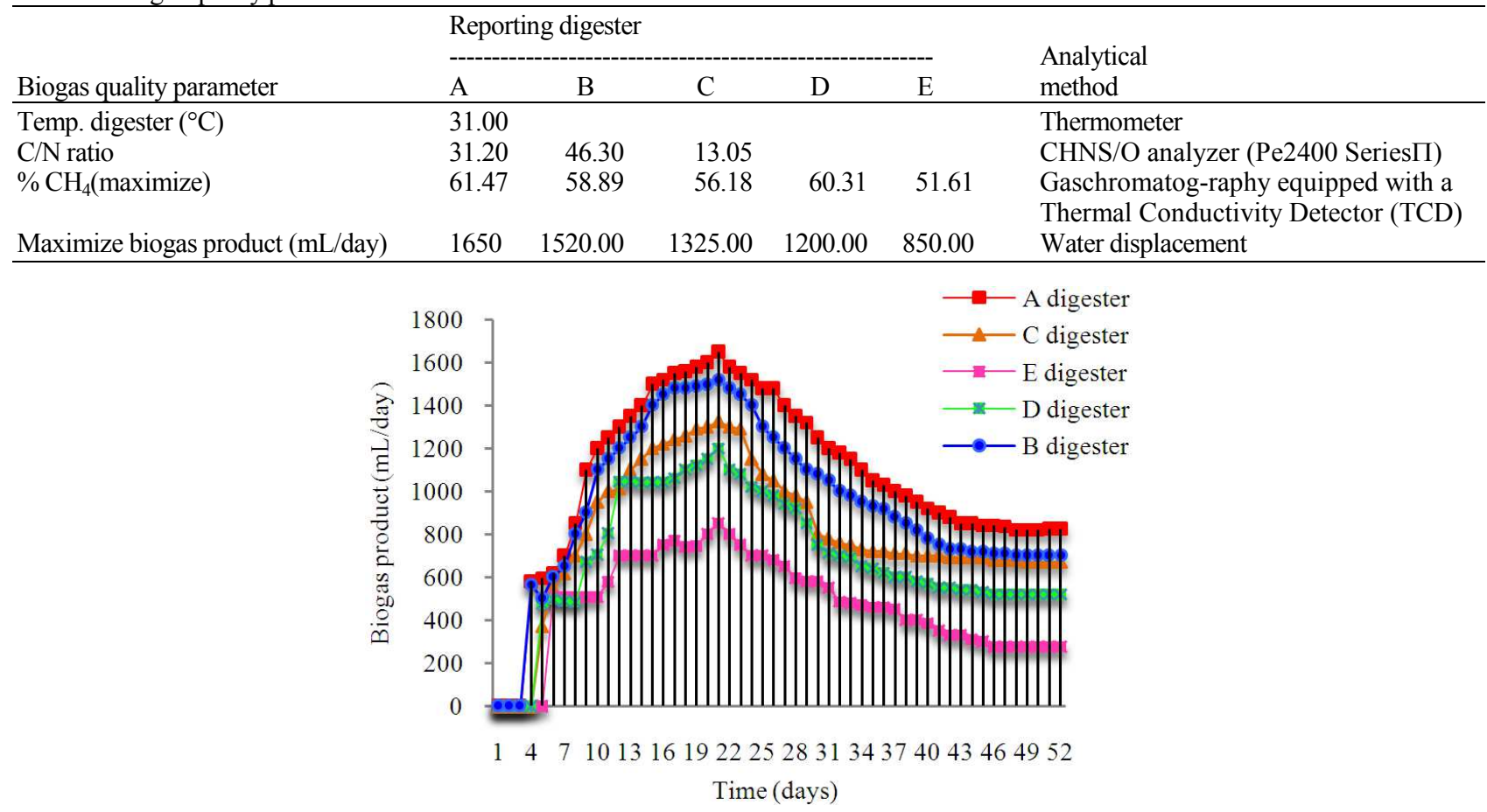

Fig. 2. Biogas production from batch co-digester at ambient temperature for 52 days in mixture experiments of natural water, cow dung, rice straw and water hyacinth

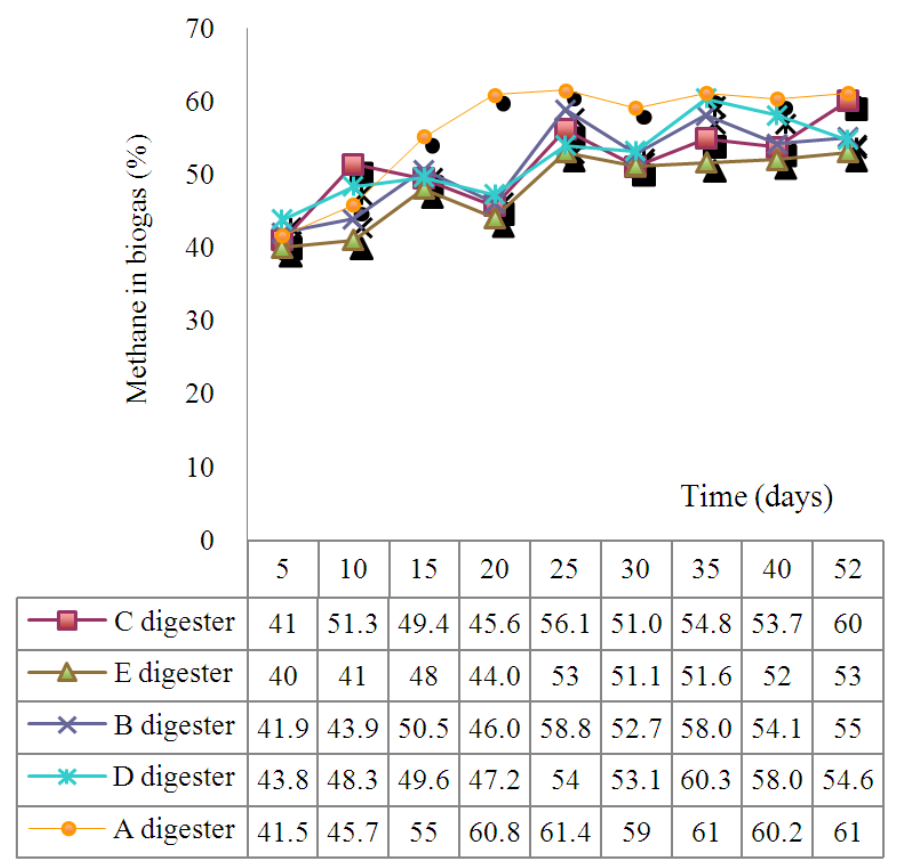

Fig. 3. Methane concentration from batch co-digester at ambient temperature for 52 days in mixture experiments of natural water, cow dung, rice straw and water hyacinth 
Methane concentrations of biogas were in the range 40-61.67\%. Changes of mixture composition in the feed did in no case cause a $\mathrm{pH}$ change by more than a half unit; $\mathrm{pH}$ value was in the range 7.1-7.4 in all experiments. Figure 3 presents the observed methane concentrations produced from experiments. It has been found that co-digestion of natural water, cow dung, rice straw and water hyacinth in the ratio $2: 1: 1: 1$ yielded maximum methane concentration of $61.47 \%$. However, the substrate without addition of rice straw (1:1:0:1 ratio of substrate) resulted in to a lowest methane concentration of $40 \%$ compared to all others substrate ratio. The results indicated that the co-digestion of natural water, cow dung, rice straw and water hyacinth in ratio 2:1:1:1 might have provided more balance nutrients and buffering capacity and thus enhanced the anaerobic bacteria activities which resulted into enhanced biogas as well as methane production. A 2:1:1:1 (digester E) has been reported to amount highest biogas and methane concentration.

From all results, it has been found that the biogas quality parameter in all digester is shown in Table 5.

\section{DISCUSSION}

Promotion of biogas technology can bring good benefits to farmers and agro-industries. Meanwhile it helps in improving national energy, environment and economic performances. For standard biogas operation, elevating fermentation efficiency can increase all indices up to $10 \%$, which significantly surpasses other options. Biogas can be used for substituting coal and electricity (Bin and Chen, 2013).

Experimental results indicate that the suitable raw material ratio of natural water, cow dung, rice straw and water hyacinth for biogas production is 2:1:1:1. For maximum biogas and methane production and appropriate carbon to nitrogen $(\mathrm{C}: \mathrm{N})$ ratio must be followed. In the other hand, it has been reported that for efficient biogas production, the optimum $\mathrm{C}: \mathrm{N}$ ratio is 20-30. This experiment confirmed that the $\mathrm{C}: \mathrm{N}$ ratio 31.2 (natural water, cow dung, rice straw and water hyacinth in the ratio $2: 1: 1: 1)$ canproduce the highest biogas volume and methane concentration.

The $\mathrm{C}: \mathrm{N}$ ratio of raw materials also affects the methanogen. A high $\mathrm{C}: \mathrm{N}$ ratio is an indication of rapid consumption of nitrogen by methanogenic and will no longer react on the left over carbon content of the material, which resulted in lower gas production. A lower $\mathrm{C}: \mathrm{N}$ ratio causes ammonia accumulation in the form of ammonia $\left(\mathrm{NH}_{4}\right)$. $\mathrm{NH}_{4}$ will increase the $\mathrm{pH}$ value of the content in the digester, which is toxic to methanogenic bacteria and $\mathrm{pH}$ will be had values exceeding 8.5. Due to, the natural water to raw materials depends on the biodegradation of agricultural wastes in anaerobic digestion. Therefore, the samples of the biogas production at different ratio of raw materials were subjected to gas analysis. The trends were in close agreement, showing that the ratio of natural water to raw materials with an increase in the natural water, compared to the corresponding ratio of the biogas product as shown in Fig. 2.

\section{CONCLUSION}

The experimental evaluate biogas production from natural water with cow dung and agricultural waste at ambient temperature for 52 days. The results support that cow dung is possible feedstock for anaerobic digestion on batch reactor 5L capacity and the productivity is improved by mixing with natural water, rice straw and water hyacinth. An anaerobic digestion of mixture raw materials without rice straw indications of lowest the biogas product and methane concentration compared to those others composition. The codigestion of natural water, cow dung, rice straw and water hyacinth in the ratio of $2: 1: 1: 1$ (C:N ratio at 31.1:1) had been found the most suitable mixture for optimum biogas production and methane concentration.

\section{ACKNOWLEDGMENT}

Authors gratefully acknowledge the provision of Scientific and Technological Research Equipment, Chulalongkorn University and King's Mongkut University of Technology Thonburi.

\section{REFERENCES}

Bin, C. and S. Chen, 2013. Life cycle assessment of coupling household biogas production to agricultural industry: A case study of biogas-linked persimmon cultivation and processing system. Energy Policy, 62: 707-716. DOI: 10.1016/j.enpol.2013.07.084

Feiqing, D. and J. Lu, 2013. Using solar energy to enhance biogas production from livestock residue-A case study of the Tongren biogas engineering pig farm in South China. Energy, 57: 759-765. DOI: 10.1016/j.energy.2013.05.046

Gupta, P., R.S. Singh, A. Sachan, A.S. Vidyarthi and A. Gupta, 2012. Study on biogas production by anaerobic digestion of garden-waste. Fuel, 95: 495498. DOI: $10.1016 /$ j.fuel.2011.11.006 
Ling, C., Z. Lixin, C. Ren and W. Fei, 2012. The progress and prospects of rural biogas production in China. Energy Policy, 51: 58-63. DOI: 10.1016/j.enpol.2012.05.052

Mohammadi, M., B. Ghobadian, G. Najafi and R. Janzadeh, 2013. Potential of biogas production in Iran. Renewable Sustainable Energy Rev., 28: 702714. DOI: 10.1016/j.rser.2013.08.021

Mohd, S., S. Hisham and M. Wan, 2008. Effect of nitrogen source and carbon to nitrogen ratio on hydrogen production using C. acetobutylicum. Am. J. Biochem. Biotechnol., 4: 393-401. DOI: 10.3844/ajbbsp.2008.393.401
Momoh, O.L. and L. Nwaogazie, 2011. The effect of waste paper on the kinetics of biogas yield from the co-digestion of cow dung and water hyacinth. Biomass Bioenergy, 35: 1345-1351. DOI: 10.1016/j.biombioe.2010.12.033

Nasir, I.M., I. Mond, R. Omar and A. Idris, 2012. Palm oil mill effluent as an additive with cattle manure in biogas production. Procedia Eng., 50: 904-912. DOI: $10.1016 /$ j.proeng.2012.10.098 